\title{
Angle Class II correction with MARA appliance
}

\author{
Kelly Chiqueto1, José Fernando Castanha Henriques², Sérgio Estelita Cavalcante Barros³, Guilherme Janson4
}

Objective: To assess the effects produced by the MARA appliance in the treatment of Angle's Class II, division 1 malocclusion. Methods: The sample consisted of 44 young patients divided into two groups: The MARA Group, with initial mean age of 11.99 years, treated with the MARA appliance for an average period of 1.11 years, and the Control Group, with initial mean age of 11.63 years, monitored for a mean period of 1.18 years with no treatment. Lateral cephalograms were used to compare the groups using cephalometric variables in the initial and final phases. For these comparisons, Student's $t$ test was employed. Results: MARA appliance produced the following effects: Maxillary growth restriction, no change in mandibular development, improvement in maxillomandibular relationship, increased lower anterior facial height and counterclockwise rotation of the functional occlusal plane. In the upper arch, the incisors moved lingually and retruded, while the molars moved distally and tipped distally. In the lower arch, the incisors proclined and protruded, whereas the molars mesialized and tipped mesially. Finally, there was a significant reduction in overbite and overjet, with an obvious improvement in molar relationship. Conclusions: It was concluded that the MARA appliance proved effective in correcting Angle's Class II, division 1 malocclusion while inducing skeletal changes and particularly dental changes.

Keywords: Angle’s Class II malocclusion. Functional orthodontic appliances. Mandibular advancement.

Objetivo: avaliar os efeitos proporcionados pelo aparelho MARA no tratamento da má oclusão de Classe II, 1ª divisão. Métodos: utilizou-se uma amostra de 44 jovens, divididos em dois grupos - Grupo MARA, com idade inicial média de 11,99 anos e tratado com o aparelho MARA por um período médio de 1,11 ano; e Grupo Controle, com idade inicial média de 11,63 ano e observado por um período médio de 1,18 ano, sem nenhum tratamento. Utilizou-se as telerradiografias em norma lateral para comparar os grupos quanto às variáveis cefalométricas das fases inicial e final. Para essas comparações, aplicou-se o teste t de Student. Resultados: o aparelho MARA proporcionou efeitos na restrição do crescimento maxilar, sem nenhuma alteração do desenvolvimento mandibular, com melhora da relação maxilomandibular, aumento da altura facial anteroinferior e inclinação anti-horária do plano oclusal funcional. $\mathrm{Na}$ arcada superior, os incisivos foram lingualizados e retruídos, e os molares foram distalizados e inclinados para distal. Na arcada inferior, ocorreu vestibularização e protrusão nos incisivos, e mesialização e inclinação mesial dos molares. Por fim, observou-se uma redução significativa nos trespasses horizontal e vertical, e uma melhora evidente na relação molar. Conclusão: pode-se concluir que o aparelho MARA foi eficaz na correção da má oclusão de Classe II, $1^{\underline{a}}$ divisão, promovendo alterações esqueléticas e, principalmente, dentárias.

Palavras-chave: Má oclusão Classe II de Angle. Aparelhos ortodônticos funcionais. Avanço mandibular.

${ }^{1} \mathrm{MSc}$ and $\mathrm{PhD}$ in Orthodontics, FOB-USP. Coordinator of the Specialization Course in Orthodontics, ABCD-BA.

${ }^{2}$ Full Professor, Pediatric Dentistry, Orthodontics and Social Health Department, FOB-USP.

${ }^{3}$ Post-Doc in Orthodontics, FOB-USP. Adjunct Professor of Orthodontics, Federal University of Rio Grande do Sul, UFRGS.

${ }^{4}$ Full Professor and Head of the Pediatric Dentistry, Orthodontics and Social Health Department, FOB-USP.

Submitted: March 31, 2009 - Revised and accepted: May 22, 2009
How to cite this article: Chiqueto K, Henriques JFC, Barros SEC, Janson G. Angle Class II correction with MARA appliance. Dental Press J Orthod. 2013 Jan-Feb; 18(1):35-44.

" The author reports no commercial, proprietary or financial interest in the products or companies described in this article.

" Patients displayed in this article previously approved the use of their facial and intraoral photographs.

Contact address: Kelly Chiqueto

Av. Bento Gonçalves, 1515 - apto 1904C, Santo Antônio - Porto Alegre/RS CEP: 90.650-002 -E-mail: kellychiqueto@yahoo.com.br 


\section{INTRODUCTION AND LITERATURE REVIEW}

Although functional appliances have been around for quite some time, their use, mode of action and effects are still shrouded in controversy. Deciding on the most effective technique to use in the treatment of growing patients with Class II malocclusion has been the subject of much debate in orthodontic literature. Advocates of functional appliances highlight their role in stimulating mandibular growth as a result of positioning the mandible anteriorly. ${ }^{16}$ Histological studies in animals have consistently shown a significant increase in cell activity when the mandible is kept in an advanced position. ${ }^{34,35}$ In this context, it is speculated that a similar effect can be seen in humans using functional appliances, thereby helping to correct Class II malocclusion. ${ }^{16}$

The fact that functional appliances are not successful is generally attributed to a lack of patient compliance in the use of the appliances and also to severity of the malocclusion. ${ }^{8}$ Therefore, to be effective in treating Angle's Class II, division 1 malocclusion, an appliance should generate the skeletal and dental effects necessary to correct the discrepancy between the basal bones while reducing overjet, thus eliminating the need for patient compliance. Such appliance would also ideally allow the simultaneous (orthopedic and orthodontic) placement of a fixed orthodontic appliance in one single step, thereby speeding up treatment. Thus, Class II correction would be facili-
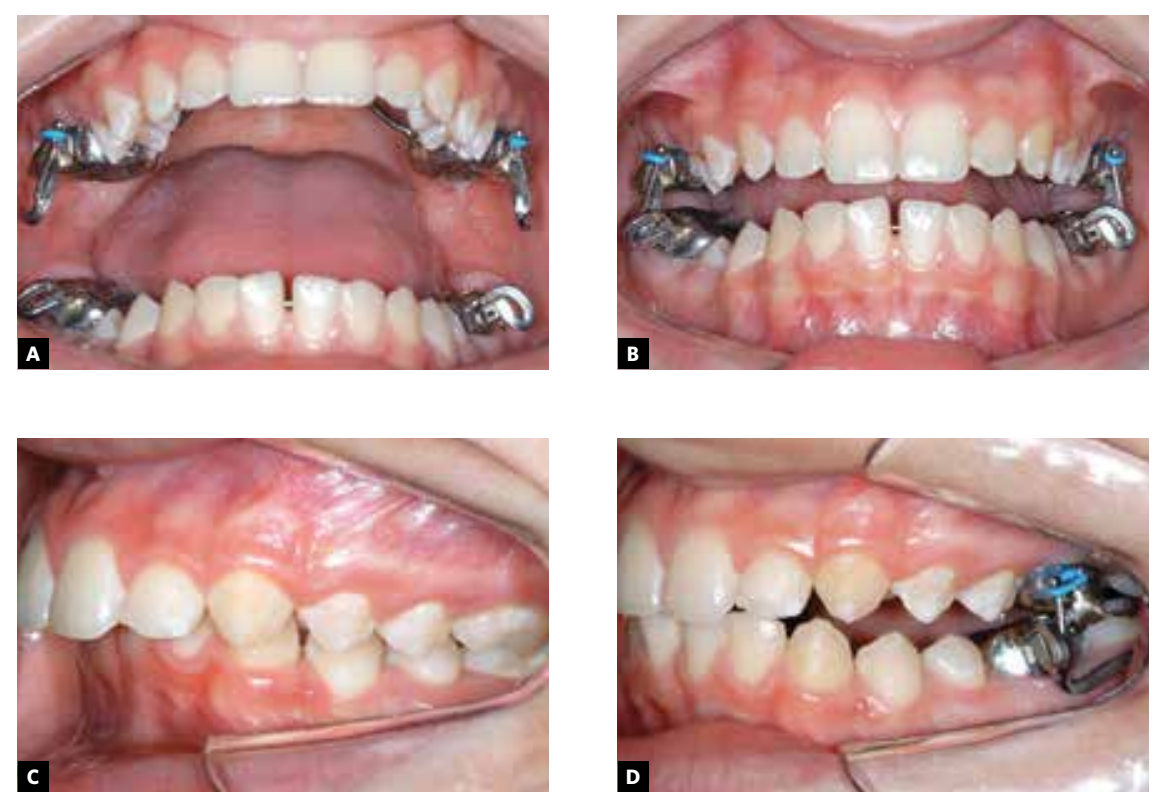

Figure 1 - A) MARA appliance in place with its components. B) The loops on the crowns create occlusal interference and hinder Class II occlusion. C, D) Photos taken before and after placement of the appliance. tated since it would perform aligning and leveling, while at the same time correcting the anteroposterior relationship. This advantage is not observed in nonextraction Class II treatment using a fixed orthodontic appliance combined with headgear or elastics, since patient compliance would still be an issue, as is the case with removable functional appliances.

Mandibular Anterior Repositioning Appliance (MARA) is a fixed functional appliance, which therefore works irrespective of patient cooperation. It comprises four steel crowns cemented on the permanent first molars (Fig 1). These crowns have loops that connect only when the patient occludes. ${ }^{2,10}$ Given that the MARA does not feature any systems involving telescopic tubes or springs connecting the jaws permanently, it allows greater freedom of mandibular movement. ${ }^{10}$ A lingual arch and transpalatal bar are incorporated to the appliance to stabilize the upper and lower molars, respectively.

Once installed, the appliance prevents the mandible from closing in a more retruded or in a Class II position, quickly teaching the patient to position the mandible anteriorly both during function and at rest. Mandibular advancement can be accomplished by inserting steel bands in the loop of the upper crown. There are four band sizes ranging from 1 to $4 \mathrm{~mm}$ in length. Thus, advancement can be gradual, while the patient is given the opportunity to adapt to the appliance.

The MARA allows concurrent use with a rapid maxillary expansion appliance and a total or partial fixed orthodontic appliance. To achieve orthopedic effects, a treatment time of 12 months is recommended..$^{25}$

Some studies describe the skeletal and dental effects produced by the MARA. 10,11,13,26,28 However, only two systematic studies have been published on the dental and skeletal changes observed in the correction of Class II, division 1. In 2003, Pangrazio-Kulbersh et $\mathrm{al}^{26}$ evaluated the cephalometric effects produced by the MARA in 30 patients (12 male and 18 female) 
with initial ages ranging from 9.5 to 15.8 years, after a mean treatment time of 10.7 months (8-17 months), and compared these with patients treated using the Herbst and Fränkel appliances and with patients with untreated Class II malocclusion. Results showed that the MARA appliance was effective in correcting Class II malocclusion by means of skeletal and dental changes. Proper molar relationship was obtained by means of $47 \%$ of skeletal changes and $53 \%$ of dental changes. Skeletal changes showed an increase in mandibular length and in anterior and posterior facial heights, but were ineffective in redirecting the maxilla. On the other hand, the dental effects included distalization of maxillary molars, mesialization of molars and incisors, and mild proclination of the lower incisors. In comparing the MARA with the Fränkel and Herbst appliances, the former showed greater dentoalveolar effects than Fränkel, and less maxillary redirecting and less inclination of maxillary incisors than the Herbst.

Another study ${ }^{11}$ only assessed the effects of the MARA appliance on the lower incisors in children (10.6 years), adolescents (14.9 years) and adults (33.7 years). It was used concurrently with a fixed orthodontic appliance for a period of 1.7 years in children, 1.3 years in adolescents, and 1.5 years in adults. In children, it was observed that the incisors protruded by $0.4 \mathrm{~mm}$ and inclined labially by $1.7^{\circ}$. Adolescents showed a $1.0 \mathrm{~mm}$ protrusion and a $3.6^{\circ}$ proclination, whereas in adults, there was a $1.7 \mathrm{~mm}$ protrusion and $4.5^{\circ}$ proclination. They therefore concluded that the MARA appliance was effective in treating Class II patients in all groups, and the changes in the lower incisors were more substantial in adults than in adolescents and children. These changes were regarded as negligible compared to other fixed functional appliances, whereas the use of the MARA combined with a fixed orthodontic appliance allowed a good control of lower incisor inclination.

More conclusive studies about the major dental and skeletal changes that result from the use of the MARA appliance are warranted as evaluations to support the evidence of such changes are extremely important. The main reason being that MARA is a fixed oral appliance designed to correct Class II malocclusion irrespective of patient compliance. It is thus an extremely effective and rapid solution for this kind of malocclusion. ${ }^{32}$ Therefore, this study aimed to evaluate through lateral cephalograms the skeletal and dental effects produced by the MARA appliance during correction of Angle's Class II, division 1 malocclusion.

\section{MATERIAL AND METHODS}

This research project was approved by the Ethics Committee of the School of Dentistry of Bauru (FOBUSP) and all patients signed an informed consent form before participating in the study.

Inclusion criteria were as follows: Bilateral Angle's Class II, division 1 malocclusion, mandibular retrusion, no agenesis or loss of permanent teeth, no supernumerary teeth, no crowding or only mild crowding in the upper and lower dental arches, moderate or severe overjet, no previous orthodontic treatment. Thus, the sample consisted of 44 young patients divided into two groups.

The MARA group comprised 22 patients, 15 male and 7 female, with initial mean age of 11.99 years \pm 1.20 years $($ minimum $=10.30$, maximum $=15$ years $)$ treated with the MARA orthopedic appliance for an average of 1.00 year (minimum $=0.77$, maximum $=1.25$ years ).

Patients started orthopedic treatment with the MARA appliance and were treated by the same student of the Doctoral Course in Dentistry, area of concentration: Orthodontics, FOB-USP. Care was taken to insert the appliance within one month after the initial radiograph was taken. The MARA was installed with a transpalatal bar and a lingual arch in all patients. Only one patient presented initially with posterior crossbite involving only the first molars and was then subjected to rapid maxillary expansion with a Hyrax appliance. The patients in this group were not subjected in advance to tooth alignment and leveling, nor interproximal stripping. All were treated until $2 \mathrm{~mm}$, on average, beyond Class I molar relationship was obtained. Malocclusion correction was deemed successful when an occlusion in centric relation was achieved, i.e., when the mandible was positioned in a centric relation (CR) that matched the position of maximum intercuspation (MI). After achieving this relationship, the appliance was kept in place for 6 months for retention purposes. The MARA appliance was thereafter removed and the patient's final radiograph taken.

" The Control Group comprised 22 patients, 15 male and 7 female, who did not undergo any type of orthodontic or orthopedic functional treatment during the observation period evaluated in this study. 
The initial mean age was 11.63 years \pm 1.03 years $($ minimum $=10.16$, maximum $=13.88$ years $)$; they were then monitored for a mean period of 1.18 years ( minimum $=0.80$, maximum $=2.01$ years $)$.

The patients were selected from a sample provided by the Center for the Study of Growth, FOB-USP, where a group of children was X-rayed and checked annually by the Department of Orthodontics with the purpose of developing a longitudinal sample of occlusions in children spanning from primary to permanent dentition. Subsequently, all patients were referred for orthodontic treatment, but some either chose to postpone intervention to a later date, or showed no interest in the treatment, which allowed the authors to define a control group.

The 44 children in the study sample met the following criteria:

» Bilateral Angle's Class II, division 1 malocclusion.

" Mandibular retrusion.

"No agenesis or no permanent teeth missing.

"No supernumerary teeth.

" No crowding, or mild crowding in the upper and lower arches.

» Moderate or severe overjet.

» No previous orthodontic treatment.

\section{Cephalometric method}

The cephalometric tracing was performed on acetate tracing paper (Ultraphan) by the same researcher and then digitized (Numonics AccuGrid xnT, model A30TL.F - Numonics Corporation, Montgomeryville, Pa). Data were analyzed with Dentofacial Planner 7.2 software (Dentofacial Planner Software Inc., Toronto, Ontario, Canada); a 9.8\% magnification factor was corrected in the radiographs of the MARA Group MARA and 6\% in the radiographs of the Control Group, since they were taken by different $\mathrm{X}$-ray machines.

The lines and reference planes used in the study are shown in Figure 2A, comprising:
A) Line $\mathrm{SN}$.
B) Frankfort plane.
C) Palatal plane.
D) Functional occlusal plane.
E) Mandibular plane - GoGn.
F) Mandibular plane - GoMe.
$\mathrm{G})$ Long axis of the upper incisor.

H) Long axis of lower incisor.

I) Long axis of the molar.

J) Long axis of the molar.

K) NA line.

L) NB line.

M)ANSperp line.

N) Pogperp line.

The skeletal cephalometric measures are shown in Figure 2B, the dental measures are shown in Figure 2C and the dental relations corresponding to overjet $(\mathrm{OJ})$, overbite (OB) and molar ratio (MR) are shown in Figure $2 \mathrm{D}$.

Superimposition of initial and final tracings in the MARA group.

\section{Statistical analysis and method error}

Statistical analysis was performed with Statistica for Windows 6.0 software (StatSoft Inc.). All results were considered statistically significant at $\mathrm{p}<0.05$.

To evaluate the method error, 20 randomly selected radiographs were once again traced and measured. Paired $t$ test was applied in order to estimate systematic error. To evaluate random error, Dahlberg's test was used with the following formula: $\mathrm{Se}^{2}=\sum \mathrm{d}^{2} / 2 \mathrm{n}$, where Se stands for Dahlberg's error; $\mathrm{d}^{2}$ is the sum of the squares of the differences between the first and second measurements, and $2 \mathrm{n}$ represents twice the number of cases in which the measurements were repeated.

Before starting the comparisons between groups, Kolmogorov-Smirnov test was applied and revealed that all variables had a normal distribution, thus allowing the application of parametric statistical tests.

Initial cephalometric compatibility and comparison of cephalometric changes were assessed using Student's $t$ test.

\section{RESULTS}

Table 1 depicts the results of assessing initial cephalometric compatibility between the groups. It was observed that overjet was the only measure that showed statistically significant difference, with the MARA group reaching the highest overjet values.

To differentiate the effects produced by the functional appliance on the normal growth that occurred during the evaluation time, the changes found in cephalometric variables for MARA were compared with those of the Control Group (Table 2). As regards to skeletal changes, the results showed that in 

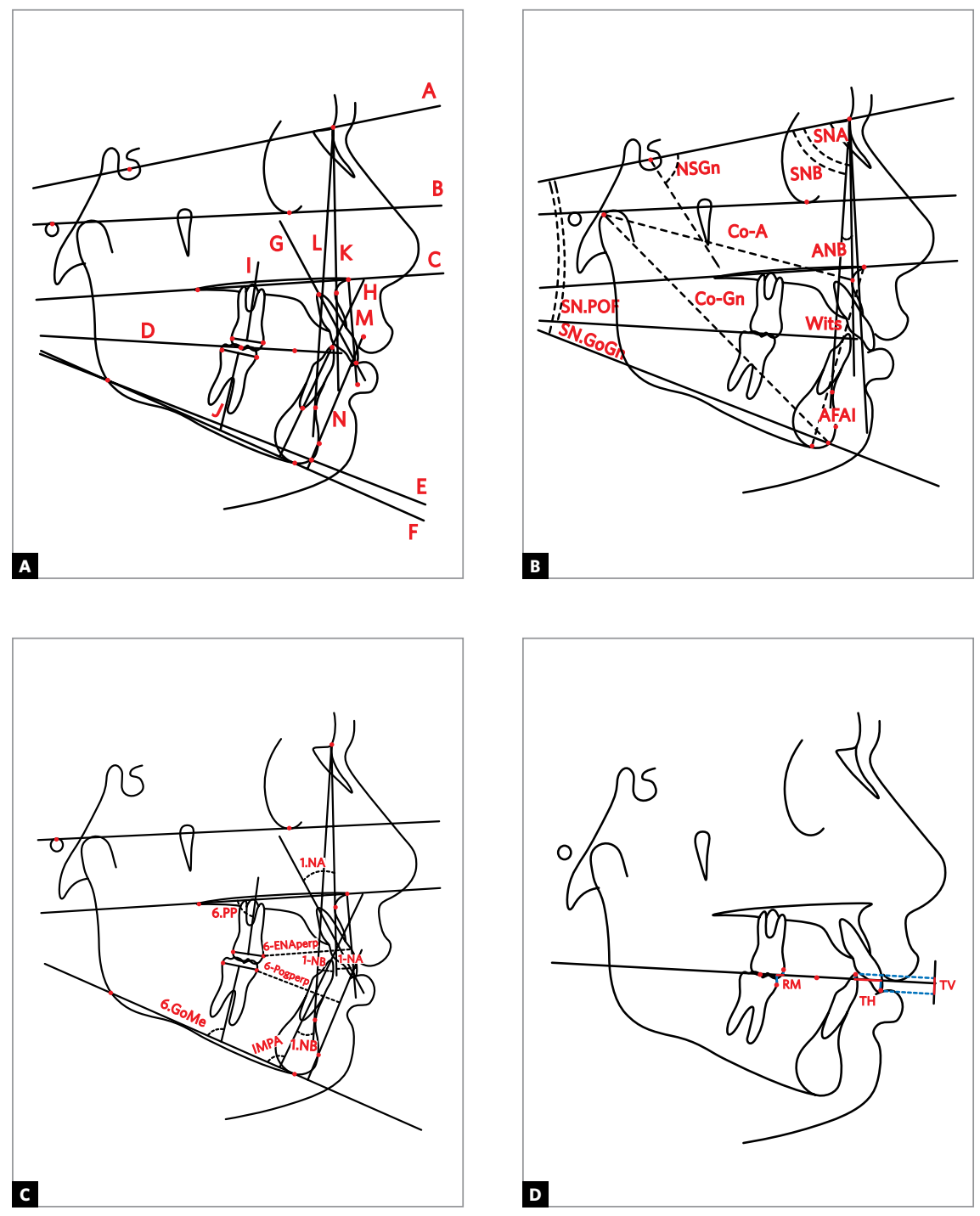

Figure 2 - Cephalometric tracings. A) Reference lines and planes. B) Skeletal cephalometric measures. C) Dental cephalometric measures. D) Dental relations: overjet $(\mathrm{OJ})$, overbite $(\mathrm{OB})$ and molar relationship (MR).

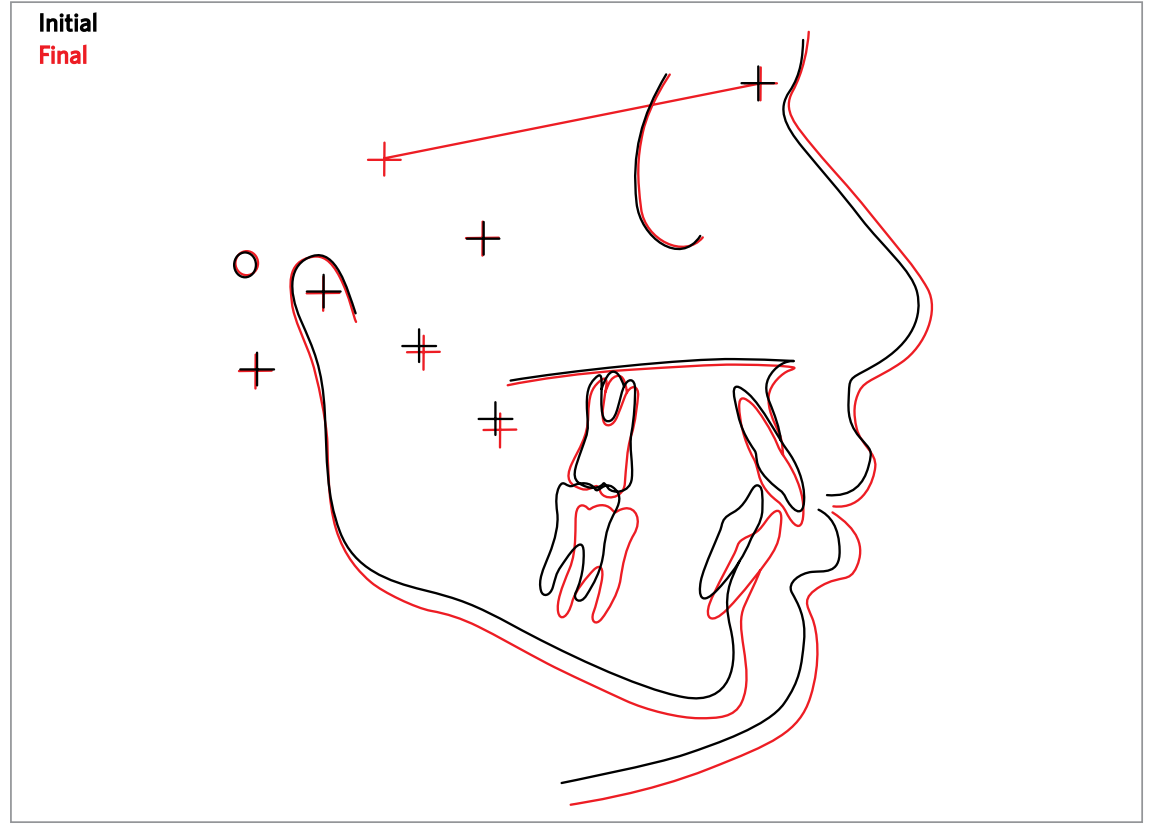

Figure 3 - Superimposition of initial and final tracings in the MARA group. 
the MARA group, the maxilla showed a slight retrusion and less growth. The mandible showed no significant differences in length and position, the maxillomandibular relationship improved significantly, the growth pattern was not affected, the lower anterior facial height increased and the occlusal plane experienced a counterclockwise rotation. The dentoalveolar changes found in the MARA Group were: Greater lingual inclination and retrusion of upper incisors, crown distalization and distal tipping of the long axis of the upper molars, considerable buccal inclination and protrusion of the lower incisors, and mesialization and mesial tipping of mandibular molars. A reduction in overjet and overbite was noted in the dental relations as well as a significant improvement in the molar relationship in the MARA Group.

\section{DISCUSSION}

The initial degree of compatibility between study groups directly influences the reliability of the results of any cephalometric study. In this study, the groups were compatible in terms of initial age, observation time, gender distribution, initial severity and all cephalometric variables, except overjet, which appeared greater in the MARA Group. A difference between groups can be ascribed to the need for a greater overjet that enabled mandibular advancement until the total correction of anteroposterior discrepancy between the arches was reached. Since the Control Group did not follow this protocol, some anterosuperior crowding was to be expected, which may have contributed to a smaller overjet.

Considering the skeletal changes produced by the MARA appliance, there was a restriction in maxillary

Table 1 - Results of $t$ test to assess initial cephalometric compatibility between groups.

\begin{tabular}{|c|c|c|c|}
\hline Variables & MARA $(n=22)$ & Control $(n=22)$ & $\mathbf{p}$ \\
\hline SNA (degrees) & $81.12 \pm 3.03$ & $80.64 \pm 3.74$ & 0.645 \\
\hline Co-A (mm) & $85.12 \pm 3.89$ & $83.33 \pm 5.23$ & 0.203 \\
\hline SNB (degrees) & $75.89 \pm 2.83$ & $75.95 \pm 3.93$ & 0.954 \\
\hline Co-Gn (mm) & $105.54 \pm 5.36$ & $104.10 \pm 6.33$ & 0.366 \\
\hline ANB (degrees) & $5.23 \pm 1.20$ & $4.69 \pm 1.88$ & 0.264 \\
\hline Wits (mm) & $4.06 \pm 2.09$ & $3.06 \pm 1.46$ & 0.072 \\
\hline SN.GoGn (degrees) & $31.30 \pm 4.53$ & $31.39 \pm 5.34$ & 0.949 \\
\hline NSGn (degrees) & $68.39 \pm 2.82$ & $67.73 \pm 4.25$ & 0.544 \\
\hline $\mathrm{LAFH}(\mathrm{mm})$ & $61.08 \pm 3.82$ & $60.83 \pm 3.50$ & 0.822 \\
\hline SN.FH (degrees) & $20.51 \pm 4.33$ & $21.54 \pm 5.48$ & 0.495 \\
\hline 1.NA (degrees) & $25.82 \pm 5.03$ & $24.79 \pm 6.03$ & 0.542 \\
\hline 1-NA (mm) & $5.71 \pm 2.19$ & $4.90 \pm 2.16$ & 0.222 \\
\hline 6-ENAperp (mm) & $-29.18 \pm 2.14$ & $-29.99 \pm 2.40$ & 0.244 \\
\hline 6.PP (degrees) & $74.45 \pm 4.94$ & $73.41 \pm 3.72$ & 0.434 \\
\hline IMPA (degrees) & $94.91 \pm 3.84$ & $93.95 \pm 6.27$ & 0.539 \\
\hline 1.NB (degrees) & $24.63 \pm 3.44$ & $24.14 \pm 5.45$ & 0.722 \\
\hline 1-NB (mm) & $4.90 \pm 1.68$ & $4.49 \pm 1.82$ & 0.437 \\
\hline 6-Pogperp (mm) & $-29.67 \pm 1.48$ & $-30.55 \pm 2.56$ & 0.173 \\
\hline 6.GoMe (degrees) & $81.57 \pm 3.99$ & $80.58 \pm 3.55$ & 0.388 \\
\hline Overjet (mm) & $9.12 \pm 1.78$ & $7.99 \pm 1.81$ & 0.042 \\
\hline Overbite (mm) & $5.02 \pm 2.12$ & $4.09 \pm 2.41$ & 0.180 \\
\hline Molar relationship (mm) & $-1.21 \pm 1.22$ & $-0.55 \pm 1.21$ & 0.079 \\
\hline
\end{tabular}


Table 2 - Results of comparing changes in cephalometric variables of the MARA and Control groups.

\begin{tabular}{|c|c|c|c|}
\hline Variables & MARA group (n=22) & Control group (n=22) & $\mathbf{p}$ \\
\hline SNA (degrees) & $-0.64 \pm 0.89$ & $0.15 \pm 0.72$ & 0.002 \\
\hline Co-A (mm) & $0.82 \pm 1.51$ & $2.41 \pm 1.33$ & 0.000 \\
\hline SNB (degrees) & $0.81 \pm 0.85$ & $0.43 \pm 0.82$ & 0.131 \\
\hline Co-Gn (mm) & $4.23 \pm 1.80$ & $3.77 \pm 1.81$ & 0.699 \\
\hline ANB (degrees) & $-1.47 \pm 0.91$ & $-0.29 \pm 0.82$ & 0.000 \\
\hline Wits (mm) & $-3.15 \pm 1.46$ & $0.08 \pm 1.21$ & 0.000 \\
\hline SN.GoGn (degrees) & $0.45 \pm 1.16$ & $-0.19 \pm 1.07$ & 0.062 \\
\hline NSGn (degrees) & $0.32 \pm 0.68$ & $0.05 \pm 0.79$ & 0.216 \\
\hline LAFH (mm) & $2.56 \pm 1.41$ & $1.54 \pm 1.21$ & 0.013 \\
\hline SN.FH (degrees) & $-4.52 \pm 3.85$ & $-0.80 \pm 2.12$ & 0.000 \\
\hline 1.NA (degrees) & $-3.32 \pm 3.66$ & $0.05 \pm 2.88$ & 0.001 \\
\hline 1-NA (mm) & $-0.90 \pm 1.33$ & $0.34 \pm 1.30$ & 0.004 \\
\hline 6-ENAperp (mm) & $-1.79 \pm 0.96$ & $0.05 \pm 1.17$ & 0.000 \\
\hline 6.PP (degrees) & $-5.58 \pm 4.14$ & $2.18 \pm 2.45$ & 0.000 \\
\hline IMPA (degrees) & $5.39 \pm 3.81$ & $0.43 \pm 2.84$ & 0.000 \\
\hline 1.NB (degrees) & $6.60 \pm 4.07$ & $0.62 \pm 2.59$ & 0.000 \\
\hline 1-NB (mm) & $1.83 \pm 0.81$ & $0.10 \pm 0.66$ & 0.000 \\
\hline 6-Pogperp (mm) & $1.04 \pm 0.76$ & $-0.42 \pm 1.12$ & 0.038 \\
\hline 6.GoMe (degrees) & $1.00 \pm 2.62$ & $-0.42 \pm 1.95$ & 0.047 \\
\hline Overjet (mm) & $-5.46 \pm 2.01$ & $0.07 \pm 1.17$ & 0.000 \\
\hline Overbite (mm) & $-2.87 \pm 1.76$ & $0.30 \pm 1.11$ & 0.000 \\
\hline Molar relationship (mm) & $5.41 \pm 1.38$ & $0.22 \pm 0.66$ & 0.000 \\
\hline
\end{tabular}

growth due to a decrease in the SNA angle $\left(0.6^{\circ}\right)$ and much lessened growth in Co-A (0.8 mm) compared to the control group $(2.4 \mathrm{~mm})$. It should be remembered that functional appliances exert upward and backward forces on the maxilla. This "headgear effect" is caused by tension in the facial muscles in an attempt to reposition the mandible back to its uppermost and posterior-most position..$^{5,714,22}$ Given that the appliance contacts the upper arch, forces arising from the muscles and soft tissues are delivered by the appliance to the teeth and maxilla.

On the other hand, Pangrazio-Kulbersh et $\mathrm{al}^{26}$ evaluated the effects of the MARA and although the SNA and A-Nperp values indicated maxillary retrusion, this change did not prove statistically significant compared to controls, despite a decrease of $0.4^{\circ}$ and $0.2 \mathrm{~mm}$ in annualized SNA and A-Nperp values. Almeida et $\mathrm{al}^{4}$ also found no significant change in the sagittal position of the jaw after treatment with the Herbst appliance, despite a greater decrease observed in the SNA angle $\left(-0.9^{\circ}\right)$ in the Herbst group compared with controls $\left(-0.5^{\circ}\right)$.
No statistically significant difference was found between groups regarding changes in the mandible. Although a greater protrusion of the mandible was expected with the orthopedic treatment due to its permanent anterior position, changes in the Control Group were found to be similar.

The effect of functional orthopedic treatment during mandibular growth currently poses fierce controversy and disagreement among authors. Pangrazio-Kulbersh et $\mathrm{al}^{26}$ found a statistically significant increase in length and some protrusion after treatment with the MARA and with Herbst in terms of control.

Some studies also report a significant protrusion after treatment with other types of fixed functional appliances such as Jasper Jumper ${ }^{12}$ and Herbst, ${ }^{4,14,18}$ whereas other studies found no significant changes in growth or sagittal position of the mandible. .,15,20 $^{2}$

It is noteworthy that most scientific publications , $^{71,24,31}$ report an increase in the length of the mandible immediately following removal of the appliance, 
i.e., an increase in sagittal growth. Ruf and Pancherz ${ }^{30}$ concluded that the anterior-most position of the mandible after treatment appears to result from remodeling of the condylar joint and mandibular fossa. Popowich, Nebbe and Major ${ }^{27}$ conducted a review of the skeletal effects of the Herbst appliance and concluded that most studies using Magnetic Resonance Imaging (MRI) or Computed Tomography (CT) are not conclusive.

Functional appliances induce a rapid, if temporary, anterior mandibular displacement during the first phase of treatment. This anterior repositioning of the mandible extends the retrodiscal tissues which, in turn, deliver forces to the condyle and articular fossa, thereby stimulating the process of bone remodeling in this region. ${ }^{34}$ Once the stimulus is removed, the process gradually loses intensity until it reaches baseline levels. ${ }^{33}$

DeVincenzo ${ }^{9}$ reported in their study that a major relapse of mandibular length increase occurs as a result of functional orthopedic treatment during the early phase of orthodontic treatment.

It is speculated that treatment with the MARA appliance may have generated this greater stimulus towards growth in the first six months or until a centric occlusion relationship was attained $(\mathrm{CR}=\mathrm{MI})$. Thereafter, while keeping the appliance for retention, growth may have declined, and eventually the total sum was equivalent to the total mandibular growth found in the Control Group. No values were found above those genetically programmed.

There was a significant improvement in the relationship between basal bones. These changes can result from a combination of several effects on the dento-skeletal structures associated with normal craniofacial growth. In this study, the improvement observed in the relationship between basal bones may have occurred as a result of maxillary retrusion combined with normal growth and anterior displacement of the mandible.

A statistically significant increase in lower anterior facial height was observed. Pancherz ${ }^{21}$ demonstrated that the Herbst appliance caused a temporary increase in lower anterior facial height. McNamara Jr, Howe and Dischinger ${ }^{17}$ reported an increase in anterior and posterior facial height, which did not negatively influence the mandibular plane angle. Nahás ${ }^{19}$ also found that the craniofacial growth pattern was not affected by treatment with the Herbst, as observed in this study.
There was a counterclockwise rotation in the functional occlusal plane (FOP) due to extrusion of the premolars, which were used as reference in constructing the FOP. The MARA appliance allowed this extrusion due to a posterior open bite (Fig 1D), thus helping to correct the curve of Spee, and helping to determine a new FOP position.

The differences between groups are more evident and significant for the dentoalveolar variables, as noted by Almeida et al, ${ }^{3}$ Neves ${ }^{20}$ and Lima. ${ }^{15}$

Regarding changes in inclination and anteroposterior positioning of the upper incisors, these teeth exhibited lingual inclination and retrusion. The upper molars showed crown distalization and distal tipping. Distalization of first molars is advocated by some authors. ${ }^{7,17,19,24}$ Valant and Sinclair ${ }^{31}$ found that the effects of the Herbst appliance on the maxilla (restricted displacement) and on the upper teeth (molar distalization) were similar to those of a headgear.

The lower incisors tipped labially significantly in patients treated orthopedically. The MARA appliance is used as a lingual arch to stabilize mandibular molars. Since the resultant force is applied anteriorly, the effects of molar mesialization are reflected mostly in the incisors. Proclination therefore occurs in these teeth. Gönner et $\mathrm{a}^{11} \mathrm{ob}-$ served a $3.6^{\circ}$ labial inclination in adolescents, and $4.5^{\circ}$ in adults treated with the MARA appliance.

Neves $^{20}$ and Lima ${ }^{15}$ found a $2.6^{\circ}$ incisor proclination at the end of treatment with the Jasper Jumper. However, as noted by the authors, increased proclination must have occurred in the lower incisors during the period when the Jasper Jumper was in place. Later, after the Jasper Jumper was removed and during the finishing phase, there may have been some lingual inclination (retroclination) of these teeth, resulting from both natural tendency to relapse and lingual torque placed in the antero-inferior region of the rectangular archwire. In assessing the effects of the Herbst appliance on the mixed dentition, Almeida et al $1^{4}$ found a significant proclination of the incisors, reflected in a $5^{\circ}$ increase in IMPA. Pancherz and Hansen ${ }^{23}$ compared five types of lower anchorage provided by the Herbst appliance and concluded that none was effective in controlling lower incisor proclination. However, Ruf, Hansen and Pancherz ${ }^{29}$ reported that despite a considerable lower incisor proclination, no gingival recession was observed at the end of treatment, 
corroborating other authors who argue that such increased inclination has not been shown to be harmful. ${ }^{1}$

Lower molars in the MARA Group experienced mesialization and mesial tipping statistically higher than in the Control Group. In correcting Angle's Class II malocclusion it is desirable to move the molars mesially. This molar mesialization effect has been reported in several studies. ${ }^{17,21,31}$

Regarding dental relationships, overbite and overjet were significantly reduced by the MARA appliance. Furthermore, molar relationship showed significant improvement. The pronounced proclination noted in the lower incisors probably resulted from an evident correction of the molar relationship, and also contributed to a greater reduction in overbite.

\section{CONCLUSIONS}

MARA appliance was effective in correcting Angle's Class II, division 1 malocclusion, producing more dentoalveolar than skeletal effects, with skeletal changes occurring predominantly in the maxilla - where maxillary growth was restrained - , and no significant effects on the mandible. In addition, the MARA appliance increased the vertical dimension of the face. Regarding dental changes, the upper incisors were inclined lingually and retruded. The upper molars showed distalization and distal tipping. The lower incisors inclined labially and protruded. The lower molars showed mesialization and mesial tipping. The MARA caused some significant improvement in dental relations (overbite and overjet, and molar relationship).
1. Allais D, Melsen B. Does labial movement of lower incisors influence the level of the gingival margin? A case-control study of adult orthodontic patients. Eur J Orthod. 2003;25(4):343-52

2. Allen-Noble PS. Clinical management of the MARA: A manual for orthodontists and staff. Sturtevant: Ormco Corporation; 2002.

3. Almeida MR, Henriques JF, Almeida RR, Almeida-Pedrin RR, Ursi W. Treatment effects produced by the Bionator appliance. Comparison with an untreated Class II sample. Eur J Orthod. 2004:26(1):65-72.

4. Ameida MRA, Henriques JFC, Almeida RR, Ursi W, Almeida-Pedrin RR, McNamara JA Jr. Efeitos dentoesqueléticos produzidos pelo aparelho de Herbst na dentadura mista. Rev Dental Press Ortod Ortop Facial. 2006:11(5):21-34

5. Angelieri F. Comparação dos efeitos cefalométricos promovidos pelos aparelhos extrabucal cervical e pendulum [tese]. Bauru (SP): Universidade de São Paulo; 2005

6. Covell DA Jr, Trammell DW, Boero RP, West R. A cephalometric study of Class II division 1 malocclusions treated with the Jasper Jumper appliance. Angle Orthod. 1999;69(4):311-20.
7. Croft RS, Buschang PH, English JD, Meyer R. A cephalometric and tomographic evaluation of Herbst treatment in the mixed dentition. Am J Orthod Dentofacial Orthop. 1999:116(4):435-43.

8. Cureton $S L$, Regennitter F, Orbell MG An accurate, inexpensive headgear timer. J Clin Orthod. 1991;25(12):749-54

9. DeVincenzo JP. Changes in mandibular length before, during, and after successful orthopedic correction of Class II malocclusions, using a functional appliance. Am J Orthod Dentofacial Orthop. 1991;99(3):241-57.

10. Eckhart JE, White LW. Class II therapy with the Mandibular Anterior Repositioning Appliance. World J Orthod. 2003:4(2):135-44.

11. Gönner U, Ozkan V, Jahn E, Toll DE. Effect of the MARA appliance on the position of the lower anteriors in children, adolescents and adults with Class II malocclusion. J Orofac Orthop. 2007;68(5):397-412.

12. Karacay S, Akin E, Olmez H, Gurton AU, Sagdic D. Forsus Nitinol Flat Spring and Jasper Jumper corrections of Class II division 1 malocclusions. Angle Orthod. 2006;76(4):666-72. 
13. Kinzinger G, Ostheimer J, Förster F, Kwandt PB, Reul H, Diedrich P. Development of a new fixed functional appliance for treatment of skeletal Class II malocclusion first report. J Orofac Orthop. 2002:63(5):384-99.

14. Küçükkeleş N, Ithan I, Orgun IA. Treatment efficiency in skeletal Class II patients treated with the jasper jumper. Angle Orthod. 2007:77(3):449-56.

15. Lima KJS. Comparação das alterações dentoesqueléticas promovidas pelos aparelhos Jasper Jumper e Ativador combinado à ancoragem extrabucal seguido de aparelho fixo, no tratamento da má oclusão de Classe II, 1a divisão [tese]. Bauru (SP): Universidade de São Paulo; 2007.

16. McNamara JA Jr, Bookstein FL, Shaughnessy TG. Skeletal and dental changes following functional regulator therapy on Class II patients. Am J Orthod. 1985:88(2):91-110

17. McNamara JA Jr. Howe RP. Dischinger TG. A comparison of the Herbst and Frankel appliances in the treatment of Class II malocclusion. Am J Orthod Dentofacial Orthop. 1990;98(2):134-44

18. Moro A, Janson G, de Freitas MR, Henriques JF, Petrelli NE, Lauris JP. Class II Correction with the Cantilever Bite Jumper. A variant of the Herbst. Angle Orthod. 2009;79(2):221-9.

19. Nahás ACR. Estudo cefalométrico das alterações dento-esqueléticas da má oclusão de Classe I, divisão 1 tratada com o aparelho de Herbst e o aparelho extrabucal de tração occipital [tese]. Bauru (SP): Faculdade de Odontologia de Bauru, Universidade de São Paulo: 2004

20. Neves LS. Estudo comparativo dos efeitos do tratamento da má oclusão de Classe II, $1^{a}$ divisão com os aparelhos Jasper Jumper e Bionator, associados ao aparelho fixo [tese]. Bauru (SP): Faculdade de Odontologia de Bauru, Universidade de São Paulo; 2007.

21. Pancherz $\mathrm{H}$. The Herbst appliance--its biologic effects and clinical use. Am J Orthod. 1985:87(1):1-20.

22. Pancherz $\mathrm{H}$, Anehus-Pancherz $M$. The headgear effect of the Herbst appliance: a cephalometric long-term study. Am J Orthod Dentofacial Orthop. 1993:103(6):510-20.

23. Pancherz $H$, Hansen $K$. Occlusal changes during and after Herbst treatment: a cephalometric investigation. Eur J Orthod. 1986:8(4):215-28

24. Pancherz H, Zieber K, Hoyer B. Cephalometric characteristics of Class division 1 and Class II division 2 malocclusions: a comparative study in children. Angle Orthod. 1997;67(2):111-20.
25. Pangrazio-Kulbersh V Entrevista. Rev Dental Press Ortod Ortop Facial. 2008:13(2):29-33

26. Pangrazio-Kulbersh V, Berger JL, Chermak DS, Kaczynski R, Simon ES, Haerian A. Treatment effects of the mandibular anterior repositioning appliance on patients with Class II malocclusion. Am J Orthod Dentofacial Orthop. 2003:123(3):286-95.

27. Popowich K, Nebbe B, Major PW. Effect of Herbst treatment on temporomandibular joint morphology: a systematic literature review. Am J Orthod Dentofacial Orthop. 2003;123(4):388-94.

28. Rondeau B. MARA appliance. Funct Orthod. 2002:19(2):4-12, 14-6.

29. Ruf S, Hansen K, Pancherz H. Does orthodontic proclination of lower incisors in children and adolescents cause gingival recession? Am J Orthod Dentofacial Orthop. 1998;114(1):100-6

30. Ruf S. Pancherz H. Does bite-jumping damage the TMJ? A prospective longitudinal clinical and MRI study of Herbst patients. Angle Orthod. 2000;70(3):183-99

31. Valant JR, Sinclair PM. Treatment effects of the Herbst appliance. Am J Orthod Dentofacial Orthop. 1989;95(2):138-47.

32. Von Bremen J, Pancherz H. Efficiency of early and late Class II Division 1 treatment. Am J Orthod Dentofacial Orthop. 2002;121(1):31-7.

33. Voudouris JC, Kuftinec MM. Improved clinical use of Twin-block and Herbst as a result of radiating viscoelastic tissue forces on the condyle and fossa in treatment and long-term retention: growth relativity. Am J Orthod Dentofacial Orthop. 2000;117(3):247-66

34. Voudouris JC, Woodside DG, Altuna G, Angelopoulos G, Bourque PJ, Lacouture CY, Kuftinec MM. Condyle-fossa modifications and muscle interactions during Herbst treatment, Part 2. Results and conclusions. Am J Orthod Dentofacial Orthop. 2003:124(1):13-29.

35. Voudouris JC, Woodside DG. Altuna G, Kuftinec MM, Angelopoulos G, Bourque PJ. Condyle-fossa modifications and muscle interactions during Herbst treatment, Part 1. New technological methods. Am J Orthod Dentofacial Orthop. 2003;123(6):604-13. 